\title{
Answer to quiz, discussion, and conclusion
}

\author{
M.A.D.N. Munasinghe, P.G.A.N. Jayathilaka, S. J. De. S Hewavisenthi \\ Department of pathology, Faculty of Medicine, University of Kelaniya, Sri Lanka
}

\section{Answer to quiz}

Microscopy showed focal collections of round to polygonal cells with round to oval nuclei, abundant and eosinophilic cytoplasm with indistinct cell borders resembling squamous morules. Some cells with elongated nuclei resembling epithelioid cells forming granulomas (Figure 1 and 2 page 9) were noted in the stratum compactum of the endometrium. There was no cytological atypia or caseous necrosis. The extensively sampled endometrium showed non phasic glands and superficial pseudodecidualized foci of the stroma. Acid-fast stain, PAS and gram stain performed failed to demonstrate acid-fast bacilli, fungal elements or bacteria respectively.

Immunohistochemical stains showed that these aggregates of polygonal cells were negative for AE1/AE3 (Figure 3C). and CD 68 (Figure 3D) excluding the possibility of squamous morules and granuloma respectively. They showed nuclear positivity with ER and PR (Figure 3A \& 3B) confirming that these are pseudo decidualized stromal cell nodules.

\section{Discussion}

Decidualization is defined as the response of the endometrial stroma to progesterone a product of corpus luteum. Endometrial stromal decidualization is not diagnostic of pregnancy. Similar changes termed pseudodecidualization can be seen in response to exogenous progestin therapy [1].

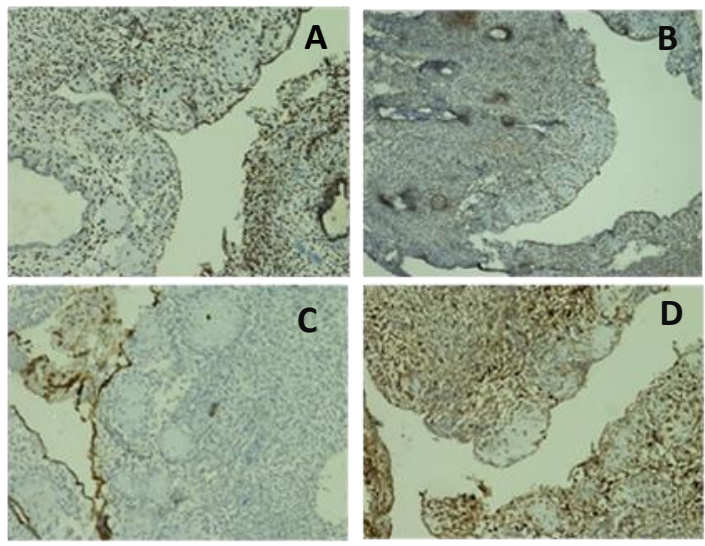

Figure 3: A- ER stain (x200), B-PR stain (100x), CAE1/AE3 stain (x200), D - CD 68 stain (x200).

Decidual cells have prominent and abundant mitochondria and RER in variable amounts [2]. Morphologically these cells are large and polygonal. They have granular, eosinophilic, abundant cytoplasm and distinct cell membranes. Nuclei are round to oval, with finely granular chromatin and small distinct nucleoli $[1,2]$. Various forms of synthetic progestins are prescribed for abnormal uterine bleeding. They are also used in the management of endometriosis, as a contraceptive and for patients taking tamoxifen for endometrial protection. The effects of progestin on the endometrium depend on the dose, the type of progestin and the degree of estrogen priming. These progestins cause atrophy of endometrial glands and expand the pseudodecidualized stroma [3]. Endometrial stromal cells express $E R$ and $P R$ as in endometrial glands. They also express CD10, bcl-2 and are negative for CD34 in contrast to cervical stromal cells which are CD 10 and bcl-2 negative, and CD 34 positive [3]. Squamous metaplasia, a common metaplastic change of the endometrium is 
mostly seen in premenopausal women. It is associated with a variety of conditions including normal and hyperplastic endometrium, chronic endometritis, intrauterine devices and as part of malignant processes $[1,4]$. Squamous metaplasia presents as isolated, non-morular surface foci or morules characterized by small, round, cohesive aggregates of immature squamous cells with indistinct cytoplasmic borders [5]. They are located within or in between glands $[1,6]$ as isolated foci detached from glands [6]. Central necrosis can be seen occasionally [6]. Uncomplicated morular metaplasia usually regress. In contrast morular metaplasia associated with endometrial intraepithelial neoplasia (EIN) usually persist and followed by adenocarcinoma in $19 \%$ cases [6].

Squamous morules are negative for $E R$ and $P R$ and are positive for pankeratin, CD10, Bcatenin (nuclear and cytoplasmic positivity) and CDX 2 [3].

Granulomata of the endometrium are rare and are usually localized to the mucosa, although $20 \%$ cases show myometrial involvement [7]. The most common cause is tuberculosis which is common in premenapausal women and rare after menopause. Caseous necrosis, which is a characteristic feature of a tuberculous granuloma is lacking due to constant shedding of endometrium during menstruation. Tubercle bacilli are usually not identified by AFB stain. Hence culture should be performed in all cases in which the morphology raises the possibility of granuloma. Other infectious causes of granulomatous inflammation are fungi, schistosomiasis, enterobius vermicularis and toxoplasma gondii [8]. Noninfectious causes are sarcoidosis, keratin granuloma and foreign body granulomas. Rarely, no obvious cause for granuloma can be found and this is termed idiopathic granulomatous endometritis (8).

\section{Conclusion}

This case highlights that pseudodecidualized stromal cells forming microscopic nodular aggregates can mimic squamous morules or granulomas. Differentiating these entities is important as treatment and management is different. Immunohistochemical markers and special stains are useful in confirming the diagnosis.

\section{References}

1. Kindelberger DW, Nucci MR. Benign endometrium: In Nucci MR, Oliva E, editors. Gynecologic pathology. 1st ed. London: Churchill Livingstone;2009. p.197-232.

2. Lowe JS, Anderson PG. Female reproductive system: In Lowe JS, Anderson PG, Anderson SI, editors.Steven \& Lowe's human histology. 4th ed. Amsterdam: Elsevier; 2015. p.337-362.

3. McCluggage $W$. Benign diseases of the endometrium: In Kurman RJ, Ellenson LH, Ronnett BM, editors. Blaustein's Pathology of the Female Genital Tract. 6th ed. Newyork: springer; 2011. p.328-338.

4. Miranda MC, Mazur MT. Endometrial squamous metaplasia: an unusual response to progestin therapy of hyperplasia. Arch Pathol Lab Med. 1995; 119: 458-460.

5. Rosai J. Metaplasia of endometrium:In Rosai J . Editor. Rosai and Ackermann's surgical pathology. Volume 2, 9th ed. Newyork: Mosby; 2004. p.1577-1675.

6. Quick CM, Nucci MR, Crum CP. Altered endometrial differentiation (Metaplasia): In Crum CP, Nucci MR, Boyd TK, editors. Diagnostic Gynecologic and Obstetric pathology. 
3rd ed. Amsterdam: Elsevier; 2018. p.

556-581.Kumar V, Abbas AK, Aster JC.

7. Inflammation and repair: In Kumar V, Abbas AK, Aster JC, editors. Robbins

Basic Pathology. 9th ed. Philadelphia:

Elsevier Saunders;2013. p. 29-75.

8. Almoujahed MO, Briski LE, Prysak M, Johnson LB, Khatib R. uterine granuloma:clinical and pathological features. American society for clinical pathology. 2002; 117: 771-775. 